\title{
Aminopurine and aminoquinazoline scaffolds for development of potential dengue virus inhibitors
}

\author{
Akkaladevi Venkatesham ${ }^{\mathrm{a}}$, Milind Saudi ${ }^{\mathrm{a}}$ Suzanne Kaptein ${ }^{\mathrm{b}}$, Johan Neyts ${ }^{\mathrm{b}}$, Jef Rozenski ${ }^{\mathrm{a}}$, \\ Mathy Froeyen ${ }^{\mathrm{a}}$, Arthur Van Aerschot ${ }^{\mathrm{a}}$ \\ ${ }^{a}$ KU Leuven, Rega Institute for Medical Research, Medicinal Chemistry, \\ Minderbroedersstraat 10, 3000 Leuven, Belgium \\ ${ }^{\mathrm{b}}$ KU Leuven, Rega Institute for Medical Research, Laboratory of Virology and \\ Chemotherapy, Minderbroedersstraat 10, 3000 Leuven, Belgium \\ * Arthur.Vanaerschot@rega.kuleuven.be; Tel. +32 16372624 \\ ${ }^{\infty}$ this is part 5 in a series on dengue virus inhibitors, part 4 being reference[1]
}

\section{Highlights}

- Some bis-aminated purine and quinazoline derivatives are envisaged as antivirals

- Different synthetic strategies have been discussed

- Activities at micromolar levels were noted for inhibition of dengue virus

- Molecular docking confirms the NS5 polymerase to be the probable target

- Bis-aminated purine and quinazoline scaffolds deserve further study as antivirals

\begin{abstract}
Previous efforts led to dicarboxamide derivatives like 1.3, comprising either an imidazole, pyrazine or fenyl ring as the central scaffold, with many congeners displaying strong inhibitory effects against dengue virus (DENV) in cell-based assays. Following up on some literature reports, the rationale was borne out to preserve the pending groups, now attached to either a 2,6-diaminopurine or 2,4-diaminoquinazoline scaffold. Synthetic efforts turned out less straightforward than expected, but yielded some new derivatives with low micromolar antiDENV activity, albeit not devoid of cellular toxicity. The purine $\mathbf{1 4}$ proved the most potent compound for this series with an EC50 of $1.9 \mu \mathrm{M}$ and a selectivity index of $>109$, while the quinazoline 18a displayed an EC50 of $2.8 \mu \mathrm{M}$ with SI of only 2.
\end{abstract}




\section{$1 \quad$ INTRODUCTION}

The dengue virus (DENV), member of the Flaviviridae, is a very common viral infection transmitted by mosquito bites.[2] Dengue incidence and prevalence are rising considerably in endemic areas of the tropical and subtropical regions. It is estimated that approximately 390 million infections occur each year[2] and cases continue to rise worldwide.[3] Indeed, global warming and increasing international contacts and travelling make up the perfect breeding ground for an exponential increase in Dengue as well as other previously exotic virus outbreaks carried by arthropods. The most recent newcomer is the Zika virus with outbreaks in Central and South America reaching pandemic levels especially in Brazil. This virus is likewise member of the Flaviviridae and related to dengue, yellow fever and West Nile viruses.[4] Like dengue it spreads through mosquito bites, and is expected to spread further over both American continents. The symptoms are usually mild, but infection of pregnant women leads to severe birth defects and poor pregnancy outcomes.[5]

Although DENV is much more prevalent and wide-spread, currently there still is neither any vaccine nor any antiviral therapy available for DENV.[6, 7] Indeed, dengue vaccine development is not straightforward, as an immunogenic response is needed against all four serotypes of DENV. When a "vaccinated" person becomes infected with a serotype against which this patient is not (or insufficiently) protected, an aggravated form of the disease will develop, due to an incompletely understood mechanism, antibody-dependent enhancement (ADE) with increased viral loads.[8] However, a tetravalent dengue vaccine under development by Sanofi-Pasteur recently was registered in Brazil.[9] This should avoid the ADE complication, but meanwhile in addition, a fifth serotype was reported[10] further complicating vaccine development.

Regarding antiviral therapy, the intensive efforts of many research groups led to a large variety of possible targets and a host of compounds have been reported to be able inhibiting DENV growth in a laboratory setting. Thus recently, a series of 2-aroyl-3-arylquinoline was reported to strongly inhibit DENV2 RNA expression without significant cell cytotoxicity.[11]. However, many more reports are appearing each year and an excellent review of Klein et al. tries to cover all aspects on the medicinal chemistry of dengue virus,[12] while another review of Soliman et al. specifically discusses the potential of targeting non-structural proteins and especially proteases for combating neglected diseases as caused by arboviruses with in particular Dengue virus.[13] In addition it was recently determined that host molecular 
chaperones like Hsp70 are required for viral entry, RNA replication and virion production and allosteric inhibitors of Hsp70 potently inhibit DENV replication.[14] We likewise recently reported on tritylated nucleosides $[15,16]$ as well as imidazole and pyrazine dicarboxamides $[1,17]$ as potential inhibitors of both Dengue and Yellow fever virus, but have not been able to uncover the mechanism of action of the latter although we suspect the RNA polymerase. Bisaryl amide compounds likewise have been reported as weak inhibitors of influenza virus, supposedly interacting with APOBEC3G, an RNA editing enzyme.[18] Finally, DENV NS5 RdRp inhibitors binding in its palm subdomain were uncovered recently using an X-ray based fragment screening methodology, resulting in low micromolar EC50 values in cell-based assays.[19]

\section{Rationale: building on previous leads}

Among our previously synthesized heterocyclic compounds, analogue 1.2 exhibited the most potent anti-DENV activity with an $\mathrm{EC}_{50}=0.5 \mu \mathrm{M}$ and a selectivity index (SI) of above 235 while the initial lead (1.1) having an imidazole dicarboxamide central scaffold displayed an $\mathrm{EC}_{50}=2.5 \mu \mathrm{M}$. In addition, evaluation of the congeners with a pyrazine central scaffold lead to compound 1.3 being the most potent congener for this series with again an $\mathrm{EC}_{50}=0.5 \mu \mathrm{M}$ and SI of over 235. In addition, the latter compound upon removal of the methyl moiety of the benzene ring at the right, displayed strong YFV inhibition with $\mathrm{EC}_{50}=0.4 \mu \mathrm{M}$ (Figure 1). Unfortunately, we have been unable to generate resistant viruses and no target so far could be pinpointed.

Insert [FIGURE1] here

Searching for structurally analogous compounds, it has been reported in literature that a series of anthranilic acid derivatives are potent inhibitors of the hepatitis C NS5B polymerase. One of the compounds (1.4, Figure 2) of this series displayed an IC50 of $17 \mathrm{nM}$ and very low cellular toxicity affording selectivity indexes over 7000 using the MTS cell proliferation assay.[20] The Novartis corporate compound archive also led to the identification of $N$-sulfonylanthranilic acid 1.5 which inhibited DENV RdRp with an $\mathrm{IC}_{50}$ of $0.7 \mu \mathrm{M}$.[21] In addition, scientists at NITD identified compound $\mathbf{1 . 6}$ as one of their inhibitors which displayed an average $\mathrm{EC}_{50}$ of $119 \mathrm{nM}$ against dengue virus serotype 2 in a human cell line.[22] In another series of compounds, 2,4-diaminoquinazoline derivative 1.7 was observed to display both the highest antiviral potency $\left(\mathrm{EC}_{50}=2.8 \mathrm{nM}, \mathrm{SI}>1000\right)$ and an excellent pharmacokinetic profile against 
DENV.[23] Finally, a series of substituted quinazoline-2,4-diamines (1.8) has been shown to display interesting anti-Leishmania activities with favorable physicochemical properties.[24]

Insert [FIGURE2] here

Combination of the structural information in these reports with our previous lead structures for DENV inhibition within the imidazole (2.1) and the phthalic acid series (2.2), inspired us to envisage compound series like $\mathbf{2 . 3}$ or $\mathbf{2 . 4}$ for their potential antiviral activity, as shown below (Figure 3). Hereto, 2,6-dichloropurine and 2,4-dichloroquinazoline are the logic precursors. Both share a 2,4-dichloropyrimidine ring allowing selective reaction to introduce different aniline substituents. A potential synthetic scheme for the quinazoline scaffold and its further derivatization is described in Scheme 1.

Insert [FIGURE3] here

Hereto, anthranilic acid 3.1 could be converted to quinazoline-2,4-diol 3.2 simply by heating in a sealed tube in the presence of urea for $12 \mathrm{hr}$. On refluxing the obtained product with $\mathrm{POCl}_{3}$ and DIPEA, it could be expected to afford 2,4-dichloroquinazoline 3.3. Further coupling of two different anilines can be done selectively by optimization of the temperature around $60^{\circ} \mathrm{C}$ and $90^{\circ} \mathrm{C}$, respectively. Both steps proceed via a straightforward $\mathrm{S}_{\mathrm{N}} \mathrm{Ar}$ mechanism on the 2,6dichloropyrimidine ring resulting in formation of product 3.5. Suzuki coupling reactions of the latter with commercially available boronic acids should afford the desired novel series of molecules 3.6.

Insert [SCHEME1] here

\section{RESULTS AND DISCUSSION}

\subsection{Synthetic procedures}

Corroborating on scheme 1, somewhat unexpectedly 2,6-dichloropurine 4 displayed no nucleophilic substitution at C6 using 2-bromo-toluidine (5) under different reaction conditions[25] (either in $\mathrm{Et}_{3} \mathrm{~N}, \mathrm{n}-\mathrm{BuOH}$ at $100{ }^{\circ} \mathrm{C}$ for $12 \mathrm{~h}$, or in $\mathrm{Et}_{3} \mathrm{~N}$, amyl alcohol, $100-110$ ${ }^{\circ} \mathrm{C}$ for $16 \mathrm{~h}$ or in presence of DIPEA in acetonitrile, $80-90{ }^{\circ} \mathrm{C}$ for $18 \mathrm{~h}$ ) (Scheme 1). Likewise, 
nucleophilic substitution at the C4 position of 2,4-dichloroquinazoline[26] (7) to obtain 8 proved not possible using 5 in either amyl alcohol or acetonitrile at elevated temperatures. This lack of reactivity could be attributed to the use of the sterically hindered electron-poor aniline[27] 5. According to the literature,[28] however, the pKa value of a trifluoroacetyl (TFA) protected aniline approaches the $\mathrm{pKa}$ for phenol (9.9 and 10.0 respectively). Activation of the sterically hindered electron-poor aniline nitrogen by a TFA group therefore will lower the pKa of the anilide 9 increasing its nucleophilicity under basic conditions. The corresponding 9 was easily obtained in 90\% yield by treatment of 5 with triflic anhydride and $\mathrm{Et}_{3} \mathrm{~N}$ in DCM at rt for $3 \mathrm{~h}$. In parallel, reaction of 2,6-dimethylquinolin-4-ol (10) with hydrazine afforded the envisaged pyrazole containing aniline 11 as described previously. [29]

Insert [SCHEME2 ] \& [SCHEME3 ] here

However, reaction of 2,6-dichloropurine (4) with 9 failed likewise to afford the desired substitution, and hence 4 was first protected on the imidazole nitrogen with 4-methoxybenzyl chloride (PMBCl) (Scheme 3). This resulted in a 2:1 mixture of the 9- and 7-PMB regioisomers[30] 12a and $\mathbf{1 2 b}$ respectively, which were conveniently separated by column chromatography.

Nucleophilic aromatic substitution at the C6-position of 12a with the acylated aniline 9 was accomplished using $\mathrm{K}_{2} \mathrm{CO}_{3}$ in 1,2-dimethoxyethane (DME) at reflux for $24 \mathrm{~h}$ to obtain $\mathbf{1 3}$ in $48 \%$ yield. Various other reaction conditions were less successful, with decreased yields using $\mathrm{NaH}$ or $\mathrm{Cs}_{2} \mathrm{CO}_{3}$ in DME, while no reaction took place with $\mathrm{K}_{2} \mathrm{CO}_{3}$ in an aprotic solvent like DMF, even at elevated temperature. Deprotection of the PMB group using TFA in DCM at rt for $5 \mathrm{~h}$ afforded $\mathbf{6}$ in 51\% yield. In contrast with 5, the hindered aniline $\mathbf{1 1}$ displayed adequate nucleophilicity and 37\% of 14 was obtained on refluxing 12a and 11 in DME for $24 \mathrm{~h}$, followed by deprotection to afford $\mathbf{1 5}$ in moderate yield. Direct substitution of $\mathbf{4}$ with $\mathbf{1 1}$ to provide $\mathbf{1 5}$ proved feasible as well on small scale in low yield (50 mg batch), albeit the reaction proved not reproducible (Scheme 3).

\section{Insert [SCHEME4] here}

As for purines, nucleophilic aromatic substitution of the quinazoline ring is directed preferably to the C4-position displaying higher reactivity. Hence, the quinazoline 7 reacted swiftly with 9 or 11 using $\mathrm{K}_{2} \mathrm{CO}_{3}$ in DME at reflux conditions to afford 8 and $\mathbf{1 6}$ in $88 \%$ and 61\%, respectively 
(Scheme 4). Further nucleophilic substitution at C2 of the quinazoline $\mathbf{1 6}$ in presence of conc. $\mathrm{HCl}$ under reflux in acetone[26] proved unsuccessful due to degradation of the starting material. Also Buchwald coupling conditions ( $\mathrm{Pd}_{2}(\mathrm{dba})_{3},[31]$ BINAP, $\mathrm{Cs}_{2} \mathrm{CO}_{3}$, Toluene, reflux for $7 \mathrm{~h}$ ) lead to degradation. Microwave conditions [32] (toluidine, EtOH, $30 \mathrm{~min}$ at $150{ }^{\circ} \mathrm{C}$ ) furnished a low yield reaction (20\%), but optimal results finally were obtained upon heating in IPA at $100{ }^{\circ} \mathrm{C}$ in a sealed tube[33] affording $66 \%$ and $46 \%$ of $18 \mathbf{a}$ and $\mathbf{1 8 b}$, respectively.

\section{Insert [SCHEME5] here}

Introduction of amines via substitution of chlorine at the C2-position of purines on many occasions in the past has shown to be problematic, especially with an electron donating nitrogen already present at C6. Ciszewski et al. carefully analyzed the problem and found slight acidic catalysis using TMSCl to be optimal.[34] However, upon treatment of $\mathbf{1 5}$ with low molecular $\%$ amounts of TMSCl in refluxing n-butanol for $12 \mathrm{~h}$, the starting material had disappeared and a brown solid was filtered, but the desired product could not be detected. Preserving the PMB group at N9 as in 14, substitution at C2-position likewise proved unsuccessful under various Buchwald-Hartwig[35] conditions with toluidine (17a) (either ( $\mathrm{Pd}(\mathrm{OAc})_{2}, \mathrm{BINAP}, \mathrm{Cs}_{2} \mathrm{CO}_{3}$, toluene, reflux; $\mathrm{Pd}_{2}(\mathrm{dba})_{3}$, $\mathrm{BINAP}, \mathrm{Cs}_{2} \mathrm{CO}_{3}$, dioxane, $\mathrm{MW}$ at $150{ }^{\circ} \mathrm{C}$ for $15 \mathrm{~min}$; or $\mathrm{Pd}(\mathrm{OAc})_{2}$, BINAP, KOtBu, toluene, reflux). Possibly, complexation of the catalyst by interaction with the pyrazole moiety causes poor reactivity of $\mathbf{1 4}$ towards palladium catalyzed cross-coupling reactions. Unfortunately, heating in IPA which was successful for the quinolone congeners, likewise did not afford the desired compound. The work on 2,6,9-trisubstituted purines of Houzé et al.[35] with prior functionalization of the C2 position starting from a C2-amine like 2-amino-6-chloropurine could have solved our issue but was not attempted further.

\subsection{Assessment of antiviral activity}

Our previous work entailing imidazole-4,5- and pyrazine-2,3-dicarboxamides targeting dengue virus (see chemical structures 1.1 - 1.3) resulted in several compounds endowed with submicromolar inhibitory acitivities and high selectivity indices. Combined with literature reports on some quinazoline derivatives displaying strong dengue inhibitory properties (structures 1.6 - 1.8), we sought to combine some features of both series in either a quinazoline or purine functionalized scaffold (see Figure 3). The resulting compounds were evaluated for their inhibitory properties against DENV (serotype 2) in Vero-B cells. Following completion of our work presented here, Vincetti et al. [36] disclosed a series of double substituted purine 
compounds with some of them displaying micromolar inhibitory effects, targeting the dengue virus NS5 polymerase at an allosteric pocket. Best results for this series were obtained for the 2,6-diaminopurine congener 1.9 with an $\mathrm{EC}_{50}$ of $5.3 \mu \mathrm{m}$ and having strong resemblance to our target compounds. Hence, the results for compounds $\mathbf{1 . 3}$ and $\mathbf{1 . 9}$ are included here in Table 1 as reference compounds.

Only for the diaminoquinazoline series the double modified target compounds $\mathbf{1 8 a}$ and $\mathbf{1 8 b}$ comprising the 3-methyl-1H-pyrazol-5-yl-phenyl moiety were attained. To our satisfaction we noted the strong inhibitory effect on denge virus proliferation $(2.6 \mu \mathrm{m}$ and $6.7 \mu \mathrm{m}$, respectively, based on RNA viral load determination), as was hoped for based on our starting rationale. However, both compounds are about 10 times less active compared to the lead dicarboxamide $1.3\left(\mathrm{EC}_{50} 0.5 \mu \mathrm{m}\right)[1]$ being at the same time much more toxic and devoid of selectivity. The mono-aminated quinazolines $\mathbf{8}$ and $\mathbf{1 6}$ proved only twice less inhibitory, but displayed lower toxicity, endowing these congeners with a selectivity index (SI) of around 10. In the purine series, the intermediate N9 or N7-methoxybenzyl protected derivatives 12a,b already displayed inhibitory activity concomitant with toxicity in the lower micromolar range, while the monoaminated purines $\mathbf{6}$ and $\mathbf{1 5}$ displayed only marginal activity around $30 \mu \mathrm{m}$ with an SI of about 5. Finally, their precursors $\mathbf{1 3}$ and $\mathbf{1 4}$ still functionalized with the methoxybenzyl moiety, proved most active and selective of this series. The pyrazolyl containing purine $\mathbf{1 4}$ herein showed most promising with an $\mathrm{EC}_{50}$ of $1.9 \mu \mathrm{m}$ and an SI of 109. Visual inspection for cell abnormalities (in contrast to inhibition of cell metabolism as determined in the MTS cell viability assay) however tempered our enthusiasm and afforded a reduced SI of only 5. In comparison, the diaminated purine $\mathbf{1 . 9}$ displayed inhibitory effects at $5 \mu \mathrm{m}$ with an SI of 32 . [36].

\subsection{Molecular docking on dengue virus NS5 polymerase}

Vincetti et al. described a novel series of dengue virus inhibitors targeting an allosteric pocket coined "cavity B" on DENV-NS5 [36] with their purine derivative 1.9 (16i in the original publication) interacting with crucial residues within this cavity. With our compounds displaying structural similarity to the reported compounds, a similar modeling study was carried out. Hereto, the envisaged compounds were docked in cavity B [37] of the dengue virus DENV-3 RNA-dependent RNA polymerase (DENV-3 RdRp NS5 pdb code 2j7u [38] being part of the NS3-NS5 protein interface. This cavity is conserved in DENV RdRps so our docking 
models based on the DENV-3 structure should be a good model for the experimental inhibition measurements obtained with DENV-2.[37]

The ligands were positioned in cavity B simulating induced fit docking by introducing flexibility in some protein residues defining cavity B (Leu326, Leu327, Lys329, Thr858, Trp859, Asn862, and Ile863). Due to high flexibility of the shallow cavity multiple binding modes for the different analogues are observed having a binding energy difference of less than $0.2 \mathrm{kcal} / \mathrm{mol}$ for different conformations. Figure 4 shows a docking pose in cavity B for several of the new reported compounds as well as for the reference compound $\mathbf{1 . 9}$ (structure 16i in the respective reference).[36] Selection of this conformation is based on the docking score (in the top 5 out of 50) and maximal hydrophobic contact with the residues Leu327, Lys329, Trp859 and Ile863, which were proven before to be important for NS3-NS5 interaction by mutational analysis. Remarkably, our docking result for this reference compound is different from the one reported by Vincetti, with 3 hydrogen bonds instead of one but absence of the reported cationpi interaction with Lys329 which was not observed in our study. However, the inhibitor shows hydrophobic contact with Lys329, Trp859 and Ile863, 3 out of 4 residues important for viral replication (no contact with Leu327, using DENV3 numbering). Using a similar procedure allowed to dock the other compounds, all binding cavity B and displaying different hydrogen bonds and hydrophobic contacts. All hydrophobic contacts with the key amino acids are given in the caption for Figure 4. The nice hydrophobic fit for $\mathbf{1 4}$ (panel D) is noteworthy. Compounds 18a and 18b (panels E and F) likewise display good interaction. From these results it seems plausible that binding may interfere with NS3-NS5 protein interaction and concomitant initiation of RNA synthesis [36] but only a qualitative interpretation can be provided.

\section{CONCLUSION}

Based on our previous findings for dicarboxamide derivatives like 1.3 endowed with strong inhibitory effects on dengue virus, and on the biological activities of 2,4-diaminoquinazoline structures as reported in literature, efforts were undertaken to combine both features based on either a central quinazoline or purine heterocyclic scaffold.

Accurate activity data were obtained using a virus yield reduction assay determining the viral RNA load by real-time quantitative RT-PCR. As hoped for, the double modified target compounds 18a and 18b displayed low micromolar inhibitory effects albeit with low selectivity. The pyrazolyl containing monocarboxylated precursor purine 14 unexpectedly 
proved to be the most active of the present series with an EC50 of $1.9 \mu \mathrm{M}$ and an SI of 109. Based on literature results, analogous molecular docking studies for our compounds confirmed the NS5 polymerase to be the probable target, highlighting the potential of bis-aminated purine and quinazoline scaffolds for further study as flavivirus inhibitors.

\section{MATERIALS AND METHODS}

\subsection{Chemistry}

General methods are largely as described before [17] and can be found in the supplementary section. Chromatographic purifications on silica gel were carried out via slow methanol gradients in dichloromethane, unless indicated otherwise.

\section{EXPERIMENTAL SECTION}

\section{$N$-(2-Bromo-4-methylphenyl)-2,2,2-trifluoroacetamide (9)}

Trifluoroacetic anhydride $(6.38 \mathrm{~mL}, 45.16 \mathrm{mmol})$ was added dropwise to a stirring solution of aniline $5(5.50 \mathrm{~g}, 31.1 \mathrm{mmol})$ and $\mathrm{Et}_{3} \mathrm{~N}(10.5 \mathrm{~mL}, 75.3 \mathrm{mmol})$ in DCM $(100 \mathrm{~mL})$ that was kept at $0^{\circ} \mathrm{C}$ with the aid of an ice bath. After 15 min the solution was allowed to warm to room temperature (rt.) and was stirred for $3 \mathrm{~h}$ more, cooled again to $0^{\circ} \mathrm{C}$ and quenched with saturated aq. $\mathrm{NaHCO}_{3}$ solution. The aqueous layer was extracted with DCM $(3 \times 100 \mathrm{~mL})$. The organic layer was separated and dried over anhydrous $\mathrm{Na}_{2} \mathrm{SO}_{4}$, filtered and concentrated under reduced pressure, and the residue was purified by column chromatography on silica gel to give $7.3 \mathrm{~g}$ $(90 \%)$ of the title compound $\mathbf{9}$ as a white solid.

${ }^{1} \mathrm{H}$ NMR $\left(300 \mathrm{MHz}, \mathrm{CDCl}_{3}\right) \delta: 8.36$ (brs, $\left.1 \mathrm{H}, \mathrm{NH}\right), 8.15$ (d, J=8.4 Hz, 1H), 7.42 (s, 1H), 7.18 (d, $J=8.4 \mathrm{~Hz}, 1 \mathrm{H}), 2.34$ (s, 3H, CH$) ;{ }^{13} \mathrm{C} \mathrm{NMR}\left(75 \mathrm{MHz}, \mathrm{CDCl}_{3}\right) \delta: 154.24$ (q, $J=37.6 \mathrm{~Hz}$ ), 137.3, 132.5, 130.3, 129.0, 121.6, 115.0 (q, $J=288.8 \mathrm{~Hz}$ ), 113.8, 20.3; HRMS for $\mathrm{C}_{9} \mathrm{H}_{8} \mathrm{BrF}_{3} \mathrm{NO}$ $\left([\mathrm{M}+\mathrm{H}]^{+}\right)$calcd.: 281.9736; found: 281.9742 .

\section{$\mathrm{N}$-Alkylation of 2,6-dichloropurine (12a, 12b)}

A mixture of 2,6-dichloropurine 4 (3 g, $15.9 \mathrm{mmol})$ and anhydrous $\mathrm{K}_{2} \mathrm{CO}_{3}(6.57 \mathrm{~g}, 47.6 \mathrm{mmol})$ in dry DMF $(100 \mathrm{~mL})$ was stirred at rt. under $\mathrm{N}_{2}$ atmosphere for $30 \mathrm{~min}$. p-Methoxybenzyl chloride $(4.3 \mathrm{~mL}, 31.7 \mathrm{mmol})$ was slowly added to the reaction mixture at $\mathrm{rt}$. and progress of the reaction was monitored by TLC. After stirring for $24 \mathrm{~h}$, the reaction mixture was filtered and evaporated in vacuo. The mixture was diluted with EtOAc $(100 \mathrm{~mL})$ and washed with $\mathrm{H}_{2} \mathrm{O}$ $(100 \mathrm{~mL})$ and the aqueous layer was back extracted twice with $100 \mathrm{~mL}$ of EtOAc. The organic 
phase was dried with $\mathrm{Na}_{2} \mathrm{SO}_{4}$ and evaporated. The product was purified by flash chromatography on silica gel to give the title compounds $\mathbf{1 2 a}$ and $\mathbf{1 2} \mathbf{b}$ as white powders.

2, 6-Dichloro-9-(4-methoxybenzyl)-9H-purine (12a): Yield: $2.71 \mathrm{~g}(55 \%) ;{ }^{1} \mathrm{H}$ NMR (300 $\left.\mathrm{MHz}, \mathrm{CDCl}_{3}\right) \delta: 8.04(\mathrm{~s}, 1 \mathrm{H}), 7.30(\mathrm{~d}, J=8.5 \mathrm{~Hz}, 2 \mathrm{H}), 6.92$ (d, $\left.J=8.5 \mathrm{~Hz}, 2 \mathrm{H}\right), 5.36$ (s, 2H, $\mathrm{PhCH}_{2}$ ), 3.82 (s, 3H, OMe); ${ }^{13} \mathrm{C}$ NMR (75 MHz, $\left.\mathrm{CDCl}_{3}\right) \delta 168.6,159.8,152.8,151.5,145.1$, 130.4, 129.4, 125.6, 114.4, 55.0, 47.4; calcd.: 331.0124; found: 331.0124.

2, 6-Dichloro-7-(4-methoxybenzyl)-7H-purine (12b): Yield: $1.3 \mathrm{~g}(26 \%) ;{ }^{1} \mathrm{H}$ NMR (300 $\left.\mathrm{MHz}, \mathrm{CDCl}_{3}\right) \delta: 8.19(\mathrm{~s}, 1 \mathrm{H}), 7.14(\mathrm{~d}, J=8.7 \mathrm{~Hz}, 2 \mathrm{H}), 6.90(\mathrm{~d}, J=8.7 \mathrm{~Hz}, 2 \mathrm{H}), 5.59(\mathrm{~s}, 2 \mathrm{H}$, $\left.\mathrm{PhCH}_{2}\right), 3.80$ (s, 3H, OMe); ${ }^{13} \mathrm{C} \mathrm{NMR}\left(75 \mathrm{MHz}, \mathrm{CDCl}_{3}\right) \delta: 163.4,159.8,152.9,149.9,143.6$, 128.6, 125.4, 121.4, 114.5, 55.1, 50.3; HRMS for $\mathrm{C}_{13} \mathrm{H}_{10} \mathrm{Cl}_{2} \mathrm{~N}_{4} \mathrm{O}_{1}\left([\mathrm{M}+\mathrm{Na}]^{+}\right)$calcd.: 331.0124 ; found: 331.0122 .

\section{$\mathrm{N}$-(2-Bromo-4-methylphenyl)-2-chloro-9-(4-methoxybenzyl)-9H-purin-6-amine (13)}

To a solution of compound 12a (60 $\mathrm{mg}, 0.19 \mathrm{mmol})$ and $9(65 \mathrm{mg}, 0.23 \mathrm{mmol})$ in DME (5 mL) was added anhydrous $\mathrm{K}_{2} \mathrm{CO}_{3}(80 \mathrm{mg}, 0.58 \mathrm{mmol})$ at $\mathrm{rt}$. and under $\mathrm{N}_{2}$. The reaction mixture was slowly heated to $60-70^{\circ} \mathrm{C}$. Further work-up was as carried out for the synthesis of 8 using $10 \mathrm{~mL}$ of EtOAc, and purification by flash chromatography on silica gel gave $43 \mathrm{mg}(48 \%)$ of the title compound $\mathbf{1 3}$ as a white solid while recovering some of the starting material 12a (15 $\mathrm{mg}, 25 \%)$.

${ }^{1} \mathrm{H}$ NMR (300 MHz, $\left.\mathrm{CDCl}_{3}\right) \delta: 8.47(\mathrm{~d}, J=8.4 \mathrm{~Hz}, 1 \mathrm{H}), 8.06(\mathrm{~s}, 1 \mathrm{H}), 7.76(\mathrm{~s}, 1 \mathrm{H}), 7.43$ (s, 1H), $7.31-7.25(\mathrm{~m}, 2 \mathrm{H}), 7.22(\mathrm{~d}, J=8.4 \mathrm{~Hz}, 1 \mathrm{H}), 6.91(\mathrm{~d}, J=8.4 \mathrm{~Hz}, 2 \mathrm{H}), 5.30(\mathrm{~s}, 2 \mathrm{H}$, $\mathrm{PhCH}_{2}$ ), 3.82 (s, 3H, OMe), $2.35\left(\mathrm{~s}, 3 \mathrm{H}, \mathrm{CH}_{3}\right) ;{ }^{13} \mathrm{C} \mathrm{NMR}\left(75 \mathrm{MHz}, \mathrm{CDCl}_{3}\right) \delta: 159.5,151.8$, $150.6,140.7,134.7,132.8,32.4,129.2,128.7,126.7,121.8,119.2,114.2,113.9,55.0,46.7$, 20.2; HRMS for $\mathrm{C}_{20} \mathrm{H}_{18} \mathrm{BrClN}_{5} \mathrm{O}\left([\mathrm{M}+\mathrm{H}]^{+}\right)$calcd.: 458.0378 ; found: 458.0378 .

\section{2-Chloro-9-(4-methoxybenzyl)- $N$-(4-methyl-2-(3-methyl-1H-pyrazol-5-yl)phenyl)-9H- purin-6-amine (14):}

Following the procedure for 13, to a mixture of compounds 12a $(0.600 \mathrm{~g}, 1.95 \mathrm{mmol})$ and 11 $(0.437 \mathrm{~g}, 2.33 \mathrm{mmol})$ dissolved in DME $(60 \mathrm{~mL})$ was added anhydrous $\mathrm{K}_{2} \mathrm{CO}_{3}(0.800 \mathrm{~g}, 5.85$ mmol) at rt. under $\mathrm{N}_{2}$. Progress of the reaction was monitored by TLC and after $24 \mathrm{~h}$ the solvent was evaporated in vacuo. The mixture was diluted with EtOAc $(60 \mathrm{~mL})$ and washed with $\mathrm{H}_{2} \mathrm{O}$ $(60 \mathrm{~mL})$ and the aqueous layers were back extracted twice with EtOAc. The organic phase was dried with $\mathrm{Na}_{2} \mathrm{SO}_{4}$ and evaporated and the product was purified by on silica gel to afford the desired product $14(0.33 \mathrm{~g}, 37 \%)$ along with partial recovery of the unreacted mixture of 12a and 11. 
${ }^{1} \mathrm{H}$ NMR (600 MHz, DMSO) $\delta: 13.14$ (s, 1H, NH), 12.16 (s, 1H, NH), 8.65 (d, J=8.5 Hz, 1H), $8.42(\mathrm{~s}, 1 \mathrm{H}), 7.58(\mathrm{~s}, 1 \mathrm{H}), 7.29$ (d, $J=8.7 \mathrm{~Hz}, 2 \mathrm{H}), 7.18$ (d, $J=8.5 \mathrm{~Hz}, 1 \mathrm{H}), 6.92$ (d, $J=8.7$ $\mathrm{Hz}, 2 \mathrm{H}), 6.59$ (s, 1H), 5.34 (s, 2H, $\left.\mathrm{PhCH}_{2}\right), 3.72$ (s, 3H, OCH $), 2.34$ (s, 3H, CH3), 2.30 (s, 3H, $\left.\mathrm{CH}_{3}\right) ;{ }^{13} \mathrm{C}$ NMR (150 MHz, DMSO) $\delta: 159.0,152.5,152.1,150.7,150.4,142.7,139.8,133.5$, 132.0, 129.1, 128.6, 128.4, 128.3, 121.4, 120.7, 119.5, 114.2, 102.6, 55.2, 46.5, 20.6, 10.4; HRMS for $\mathrm{C}_{24} \mathrm{H}_{23} \mathrm{ClN}_{7} \mathrm{O}\left([\mathrm{M}+\mathrm{H}]^{+}\right)$calcd.: 460.16470; found: 460.1652 .

\section{$\mathrm{N}$-(2-Bromo-4-methylphenyl)-2-chloro-9H-purin-6-amine (6)}

To a stirred solution of compound $13(30 \mathrm{mg}, 0.065 \mathrm{mmol})$ in DCM (5 mL) was added TFA (40 $\mu \mathrm{L}, 0.65 \mathrm{mmol}$ ) at $0^{\circ} \mathrm{C}$ under $\mathrm{N}_{2}$ atmosphere. The reaction mixture was slowly heated to $60^{\circ} \mathrm{C}$ and progress of the reaction was monitored by TLC. After $5 \mathrm{~h}$, the mixture was cooled to $0^{\circ} \mathrm{C}$ and neutralized with saturated aqueous $\mathrm{K}_{2} \mathrm{CO}_{3}$. The aqueous layer was extracted with $\operatorname{DCM}(3 \times 10 \mathrm{~mL})$. The organic layer was separated and dried over anhydrous $\mathrm{Na}_{2} \mathrm{SO}_{4}$, filtered and concentrated under reduced pressure and the residue was purified by column chromatography on silica gel to afford $11 \mathrm{mg}(51 \%)$ of the title compound 6 as a white solid. ${ }^{1} \mathrm{H}$ NMR (600 MHz, DMSO) $\delta: 9.59$ (s, 1H, NH), 8.20 (s, 1H), 7.54 (d, J=1.1 Hz, 1H), 7.53 $(\mathrm{d}, J=8.1 \mathrm{~Hz}, 1 \mathrm{H}), 7.24(\mathrm{ddd}, J=8.1 \mathrm{~Hz}, 1.8 \mathrm{~Hz}$ and $0.6 \mathrm{~Hz}), 3.66($ brs, $1 \mathrm{H}, \mathrm{NH}), 2.34$ (s, 3H, $\left.\mathrm{CH}_{3}\right) ;{ }^{13} \mathrm{C}$ NMR (150 MHz, DMSO) $\delta$ 153.6, 152.8, 152.2, 141.8, 137.4, 134.0, 133.0, 128.9, 128.0, 120.2, 117.3, 114.2, 20.2; HRMS for $\mathrm{C}_{12} \mathrm{H}_{10} \mathrm{BrClN}_{5}\left([\mathrm{M}+\mathrm{H}]^{+}\right)$calcd.: 337.9803; found: 337.9797 .

\section{2-Chloro- $N$-(4-methyl-2-(3-methyl-1H-pyrazol-5-yl)phenyl)-9H-purin-6-amine(15)}

Analogous to the procedure for 13, to a mixture of compound $4(50 \mathrm{mg}, 0.26 \mathrm{mmol})$ and 11 (60 mg, $0.32 \mathrm{mmol})$ dissolved in $\mathrm{DME}(5 \mathrm{~mL})$ was added anh. $\mathrm{K}_{2} \mathrm{CO}_{3}(109 \mathrm{mg}, 0.79 \mathrm{mmol})$ at rt. under $\mathrm{N}_{2}$. After reaction for $24 \mathrm{~h}$, the solvent was evaporated in vacuo, and the mixture was partitioned between EtOAc $(10 \mathrm{~mL})$ and $\mathrm{H}_{2} \mathrm{O}(10 \mathrm{~mL})$. The aqueous phase was back extracted twice with EtOAc. The organic phase was dried with $\mathrm{Na}_{2} \mathrm{SO}_{4}$ and evaporated. The product was purified by flash chromatography on silica gel to give $32 \mathrm{mg}(35 \%)$ of the title compound 15 as a white solid.

Alternatively, deprotection of $\mathbf{1 4}$ with TFA as described for compound $\mathbf{6}$ afforded $\mathbf{1 5 .}$

${ }^{1} \mathrm{H}$ NMR (600 MHz, DMSO) $\delta: 13.36$ (s, 1H, NH), 13.14 (s, 1H, NH), 12.10 (s, 1H, NH), 8.68 (d, $J=8.5 \mathrm{~Hz}, 1 \mathrm{H}), 8.26(\mathrm{~s}, 1 \mathrm{H}), 7.57(\mathrm{~s}, 1 \mathrm{H}), 7.17(\mathrm{dd}, J=8.5,1.4 \mathrm{~Hz}, 1 \mathrm{H}), 6.57(\mathrm{~s}, 1 \mathrm{H}), 2.33$ (s, 3H, $\left.\mathrm{CH}_{3}\right), 2.30$ (s, 3H, $\left.\mathrm{CH}_{3}\right) ;{ }^{13} \mathrm{C}$ NMR (150 MHz, DMSO) $\delta: 152.2,152.0,151.2,150.7$, $140.9,139.7,133.7,131.8,128.4,128.3,121.2,120.5,119.3,102.5,20.5,10.4$; HRMS for $\mathrm{C}_{16} \mathrm{H}_{15} \mathrm{ClN}_{7}\left([\mathrm{M}+\mathrm{H}]^{+}\right)$calcd.: 340.1072 ; found: 340.1071 


\section{N-(2-Bromo-4-methylphenyl)-2-chloroquinazolin-4-amine (8)}

To a solution of compound $7(3 \mathrm{~g}, 15.07 \mathrm{mmol})$ and the protected aniline 9 (5.08 g, 18.09 $\mathrm{mmol}$ ) in dimethoxyethane (DME, $50 \mathrm{~mL}$ ) was added anhydrous $\mathrm{K}_{2} \mathrm{CO}_{3}(6.23 \mathrm{~g}, 45.2 \mathrm{mmol})$ at rt. under $\mathrm{N}_{2}$. The reaction mixture was slowly heated to $60-70^{\circ} \mathrm{C}$. Progress of the reaction was monitored by TLC and after $6 \mathrm{~h}$, the mixture was cooled to $\mathrm{rt}$. The solvent was removed in vacuo and the mixture was diluted with EtOAc $(50 \mathrm{~mL})$ and washed with $\mathrm{H}_{2} \mathrm{O}(50 \mathrm{~mL})$ and the aqueous layer was back extracted twice with $50 \mathrm{~mL}$ of EtOAc. The organic phase was dried with $\mathrm{Na}_{2} \mathrm{SO}_{4}$ and evaporated. The product was purified by flash chromatography on silica gel to give $4.7 \mathrm{~g}(88 \%)$ of the title compound 8 as a white solid.

${ }^{1} \mathrm{H}$ NMR (600 MHz, $\left.\mathrm{CDCl}_{3}\right) \delta 8.57$ (d, $\left.J=8.5 \mathrm{~Hz}, 1 \mathrm{H}\right), 8.16$ (brs, 1H, NH), $7.96-7.77$ (m, $3 \mathrm{H}), 7.59$ (dtd, $J=8.5,6.8$ and $1.7 \mathrm{~Hz}, 1 \mathrm{H}), 7.49-7.38(\mathrm{~m}, 1 \mathrm{H}), 7.23(\mathrm{dd}, J=8.5,1.7 \mathrm{~Hz}$, 1H). 2.35 (s, $\left.3 \mathrm{H}, \mathrm{CH}_{3}\right) ;{ }^{13} \mathrm{C} \mathrm{NMR}\left(150 \mathrm{MHz} \mathrm{CDCl}_{3}\right) \delta: 157.7,156.7,151.0,135.4,133.6$, 132.4, 132.3, 128.9, 128.0, 126.8, 122.2, 120.1, 114.3, 113.4, 20.3; HRMS for $\mathrm{C}_{15} \mathrm{H}_{12} \mathrm{BrClN}_{3}$ $\left([\mathrm{M}+\mathrm{H}]^{+}\right)$calcd.: 347.9898 ; found: 347.9900 .

\section{2-Chloro- $N$-(4-methyl-2-(3-methyl-1H-pyrazol-5-yl)phenyl)quinazolin-4-amine (16)}

To a solution of $7(0.500 \mathrm{~g}, 2.5 \mathrm{mmol})$ and $11(0.563 \mathrm{~g}, 3.0 \mathrm{mmol})$ in DME (50 mL) was added anhydrous $\mathrm{K}_{2} \mathrm{CO}_{3}(1.04 \mathrm{~g}, 7.5 \mathrm{mmol})$ at $\mathrm{rt}$. under $\mathrm{N}_{2}$ atmosphere. The reaction mixture was slowly heated to $60-70^{\circ} \mathrm{C}$ for $24 \mathrm{~h}$. Further work-up was as carried out for the synthesis of $\mathbf{8}$, and purification on silica gel afforded $0.545 \mathrm{~g}(62 \%)$ of the title compound $\mathbf{1 6}$ as a pale yellow solid. ${ }^{1} \mathrm{H}$ NMR (500 MHz, DMSO) $\delta: 13.7$ (brs, 1H, NH), 12.7 (brs, 1H, NH), 7.98 (d, J=7.9 $\mathrm{Hz}, 1 \mathrm{H}), 7.87$ (t, $J=7.9 \mathrm{~Hz}, 1 \mathrm{H}), 7.79$ (s, 1H), 7.55 (d, $J=8.2 \mathrm{~Hz}, 1 \mathrm{H}), 7.42$ (t, $J=6.9 \mathrm{~Hz}$, 2H), $7.34(\mathrm{~d}, J=6.9 \mathrm{~Hz}, 1 \mathrm{H}), 6.46(\mathrm{~s}, 1 \mathrm{H}), 2.45\left(\mathrm{~s}, 3 \mathrm{H}, \mathrm{CH}_{3}\right), 2.16\left(\mathrm{~s}, 3 \mathrm{H}, \mathrm{CH}_{3}\right) ;{ }^{13} \mathrm{C} \mathrm{NMR}$ (125 MHz, DMSO) $\delta 159.4,152.4,147.8,140.5,139.2,137.7,136.2,131.1,130.3,129.9$, $129.5,127.7,125.6,125.0,116.7,115.3,102.7,21.0,10.3$; HRMS for $\mathrm{C}_{19} \mathrm{H}_{17} \mathrm{ClN}_{5}\left([\mathrm{M}+\mathrm{H}]^{+}\right)$ calcd.: 350.1166 ; found 350.1165 .

N4-(4-Methyl-2-(3-methyl-1H-pyrazol-5-yl)phenyl)-N2-(p-tolyl)quinazoline-2,4-diamine (18a):

A stirred solution of 16 (65 mg, $0.186 \mathrm{mmol})$ and 17a $(23 \mathrm{mg}, 0.22 \mathrm{mmol})$ in $5 \mathrm{~mL}$ of isopropanol was heated to $100^{\circ} \mathrm{C}$ in a closed tube. After $4 \mathrm{~h}$, a pale yellow solid was filtered and the solid was washed with a minimum amount of cold isopropanol, and dried in vacuo to afford (52 $\mathrm{mg}, 66 \%$ ) of the title compound $\mathbf{1 8 a}$ as a pale yellow solid.

${ }^{1} \mathrm{H}$ NMR (600 MHz, DMSO) $\delta: 13.28$ (brs, 1H, NH), 12.84 (brs, 1H, NH), 10.46 (brs, 1H, $\mathrm{NH}), 8.41$ (d, $J=8.2 \mathrm{~Hz}, 1 \mathrm{H}), 8.28$ (brs, $1 \mathrm{H}), 7.89$ (t, $J=7.6 \mathrm{~Hz}, 1 \mathrm{H}), 7.64$ (d, $J=8.7 \mathrm{~Hz}$, 
2H), $7.56(\mathrm{t}, J=7.6 \mathrm{~Hz}, 1 \mathrm{H}), 7.36$ (d, $J=7.9 \mathrm{~Hz}, 2 \mathrm{H}), 7.21$ (d, $J=7.3 \mathrm{~Hz}, 2 \mathrm{H}), 6.99(\mathrm{~s}, 1 \mathrm{H})$, $6.56(\mathrm{~s}, 1 \mathrm{H}), 2.35$ (s, $\left.2 \times 3 \mathrm{H}, 2 \times \mathrm{CH}_{3}\right) ; 2.30$ (s, 3H, $\left.\mathrm{CH}_{3}\right) ;{ }^{13} \mathrm{C} \mathrm{NMR}(150 \mathrm{MHz}, \mathrm{DMSO}) \delta$ $158.4,152.0,149.7,140.3,139.6,135.4,135.0,133.9,132.1,129.5,128.4,128.2,125.4$, $123.9,123.8,123.8,123.6,118.0,111.3,102.9,20.7$ (2 x C), 10.5; HRMS for $\mathrm{C}_{26} \mathrm{H}_{25} \mathrm{~N}_{6}$ $\left([\mathrm{M}+\mathrm{H}]^{+}\right)$calcd.: 421.2135 ; found: 421.2132 .

N2-(4-fluorophenyl)-N4-(4-methyl-2-(3-methyl-1H-pyrazol-5-yl)phenyl)quinazoline-2,4diamine (18b):

A stirred solution of $16(100 \mathrm{mg}, 0.286 \mathrm{mmol})$ and $17 \mathrm{~b}(38 \mathrm{mg}, 0.344 \mathrm{mmol})$ in $5 \mathrm{~mL}$ of isopropanol was heated in a closed vessel for $6 \mathrm{~h}$ at $100^{\circ} \mathrm{C}$. The precipitate formed was filtered and the solid was washed with a minimum amount of cold isopropanol and dried under vacuum to afford $56 \mathrm{mg}$ (46\%) of the title compound $\mathbf{1 8 b}$ as a pale yellow solid.

${ }^{1} \mathrm{H}$ NMR (600 MHz, DMSO) $\delta 13.27$ (brs, 1H, NH), 12.80 (s, 1H, NH), 10.45 (s, 1H, NH), 8.45 (d, $J=8.1 \mathrm{~Hz}, 1 \mathrm{H}), 8.30$ (brs, 1H), 7.91 (t, $J=7.6 \mathrm{~Hz}, 1 \mathrm{H}), 7.67$ (d, $J=6.1 \mathrm{~Hz}, 2 \mathrm{H}), 7.61$ - $7.49(\mathrm{~m}, 3 \mathrm{H}), 7.26(\mathrm{~s}, 2 \mathrm{H}), 7.05(\mathrm{~s}, 1 \mathrm{H}), 6.60(\mathrm{~s}, 1 \mathrm{H}), 2.37$ (s, 3H, $\left.\mathrm{CH}_{3}\right), 2.30\left(\mathrm{~s}, 3 \mathrm{H}, \mathrm{CH}_{3}\right)$; ${ }^{13} \mathrm{C}$ NMR (150 MHz, DMSO) $\delta 160.6,159.0,158.6,152.4,152.3,149.9,140.0,135.4,135.0$, 133.0, 132.1, 128.4, 128.2, 125.9, 125.4, 123.9, 123.6, 118.3, 118.2, 115.8, 115.7, 111.5, 103.0, 20.6, 10.5; fluorine coupled spectrum and missing quaternary signals; HRMS for $\mathrm{C}_{25} \mathrm{H}_{22} \mathrm{FN}_{6}$ $\left([\mathrm{M}+\mathrm{H}]^{+}\right)$calcd.: 425.1884 ; found: 425.1875 .

\section{Antiviral activity determination for DENV and YFV}

Antiviral activities were determined as described in detail before by Vincetti et al.[36] (and reflect the activities as determined versus Dengue virus serotype 2 in Vero B cells [African Green monkey kidney cells obtained from the European Collection of Cell Cultures (ECACC)]. Basically, in CPE-reduction assays, cells are incubated for 7 days with serial compound dilutions, both in presence and in absence of virus. Afterwards, the 50\% effective concentrations $\left(\mathrm{EC}_{50}\right)$ and the $50 \%$ cytotoxic concentrations $\left(\mathrm{CC}_{50}\right)$, which are defined as the compound concentration that is required to inhibit the virus-induced cytopathogenic effect (CPE), are calculated based on microscopic scoring data. More accurate activity data are obtained with a virus yield reduction assay, which determines the viral RNA load by real-time quantitative RT-PCR.

\section{Molecular modeling}


Using AutodockTools [39] a box of 60x60x60 units of $0.375 \AA$ was centered on atom CB of the Lys329 sidechain. Polar hydrogens were added to enzyme and ligands as well as Gasteiger charges. Docking using autodock 4.2 was performed 100 times for every molecule to explore exhaustively the conformational space. From the top 5 scores, dockings were selected based on maximal interaction with the cavity residues (manual inspection via UCSF

Chimera [40]).

Acknowledgements - Milind Saudi was beneficiary of a scholarship of the Erasmus Mundus External Cooperation Window (EMCW lot 13). Mass spectrometry was made possible by the support of the Hercules Foundation of the Flemish Government (grant 20100225-7). The antiviral work was supported by EU FP7 project SILVER (contract no HEALTH-F3-2010260644). We are indebted to Luc Baudemprez for providing NMR spectra and to C. Biernaux for final typesetting.

\section{REFERENCES}

[1] M. Saudi, J. Zmurko, S. Kaptein, J. Rozenski, B. Gadakh, P. Chaltin, A. Marchand, J. Neyts, A. Van Aerschot, Synthetic strategy and antiviral evaluation of diamide containing heterocycles targeting dengue and yellow fever virus, Eur. J. Med. Chem., (2016) Submitted.

[2] S. Bhatt, P.W. Gething, O.J. Brady, J.P. Messina, A.W. Farlow, C.L. Moyes, J.M. Drake, J.S. Brownstein, A.G. Hoen, O. Sankoh, The global distribution and burden of dengue, Nature, 496 (2013) 504-507.

[3] H.Q. Cuong, N.T. Hien, T.N. Duong, T.V. Phong, N.N. Cam, J. Farrar, V.S. Nam, K.T. Thai, P. Horby, Quantifying the emergence of dengue in Hanoi, Vietnam: 1998-2009, PLoS Neglected Trop. Dis., 5 (2011) e1322.

[4] European Centre for Disease Prevention and Control, http://ecdc.europa.eu/en/healthtopics/zika virus infection/pages/index.aspx, 2005, (accessed: 28 January 2016)

[5] Centers for Disease Control and Prevention, http://www.cdc.gov/zika/, 2015, (accessed: 28 January 2016)

[6] A.J. Stevens, M.E. Gahan, S. Mahalingam, P.A. Keller, The medicinal chemistry of dengue fever, J. Med. Chem., 52 (2009) 7911-7926.

[7] Treatment of Human Parasitosis in Traditional Chinese Medicine, 1 ed., Springer-Verlag Berlin Heidelberg, 2014.

[8] M.G. Guzman, M. Alvarez, S.B. Halstead, Secondary infection as a risk factor for dengue hemorrhagic fever/dengue shock syndrome: an historical perspective and role of antibodydependent enhancement of infection, Arch. Virol., 158 (2013) 1445-1459.

[9] L. Villar, G.H. Dayan, J.L. Arredondo-Garcia, D.M. Rivera, R. Cunha, C. Deseda, H. Reynales, M.S. Costa, J.O. Morales-Ramirez, G. Carrasquilla, L.C. Rey, R. Dietze, K. Luz, E. Rivas, M.C. Miranda Montoya, M. Cortes Supelano, B. Zambrano, E. Langevin, M. Boaz, N. Tornieporth, M. Saville, F. Noriega, C.Y.D.S. Group, Efficacy of a tetravalent dengue vaccine in children in Latin America, New Engl. J. Med., 372 (2015) 113-123. 
[10] D. Normile, Tropical medicine. Surprising new dengue virus throws a spanner in disease control efforts, Science, 342 (2013) 415.

[11] C.H. Tseng, C.K. Lin, Y.L. Chen, C.Y. Hsu, H.N. Wu, C.K. Tseng, J.C. Lee, Synthesis, antiproliferative and anti-dengue virus evaluations of 2-aroyl-3-arylquinoline derivatives, Eur. J. Med. Chem., 79 (2014) 66-76.

[12] M.A.M. Behnam, C. Nitsche, V. Boldescu, C.D. Klein, The Medicinal Chemistry of Dengue Virus, J. Med. Chem., 59 (2016) 5622-5649.

[13] S. Bhakat, W. Karubiu, V. Jayaprakash, M.E. Soliman, A perspective on targeting non-structural proteins to combat neglected tropical diseases: Dengue, West Nile and Chikungunya viruses, Eur. J. Med. Chem., 87 (2014) 677-702.

[14] S. Taguwa, K. Maringer, X. Li, D. Bernal-Rubio, J.N. Rauch, J.E. Gestwicki, R. Andino, A.

Fernandez-Sesma, J. Frydman, Defining Hsp70 Subnetworks in Dengue Virus Replication Reveals Key Vulnerability in Flavivirus Infection, Cell, 163 (2015) 1108-1123.

[15] T. De Burghgraeve, B. Selisko, S. Kaptein, G. Chatelain, P. Leyssen, Y. Debing, M. Jacobs, A. Van Aerschot, B. Canard, J. Neyts, 3',5'Di-O-trityluridine inhibits in vitro flavivirus replication, Antivir. Res., 98 (2013) 242-247.

[16] G. Chatelain, Y. Debing, T. De Burghgraeve, J. Zmurko, M. Saudi, J. Rozenski, J. Neyts, A. Van Aerschot, In search of flavivirus inhibitors: Evaluation of different tritylated nucleoside analogues, Eur. J. Med. Chem., 65 (2013) 249-255.

[17] M. Saudi, J. Zmurko, S. Kaptein, J. Rozenski, J. Neyts, A. Van Aerschot, Synthesis and evaluation of imidazole-4,5- and pyrazine-2,3-dicarboxamides targeting dengue and yellow fever virus, Eur. J. Med. Chem., 87 (2014) 529-539.

[18] L.H. Hao, Y.P. Li, W.Y. He, H.Q. Wang, G.Z. Shan, J.D. Jiang, Y.H. Li, Z.R. Li, Synthesis and antiviral activity of substituted bisaryl amide compounds as novel influenza virus inhibitors, Eur. J. Med. Chem., 55 (2012) 117-124.

[19] F. Yokokawa, S. Nilar, C.G. Noble, S.P. Lim, R. Rao, S. Tania, G. Wang, G. Lee, J. Hunziker, R. Karuna, U. Manjunatha, P.Y. Shi, P.W. Smith, Discovery of Potent Non-Nucleoside Inhibitors of Dengue Viral RNA-Dependent RNA Polymerase from a Fragment Hit Using Structure-Based Drug Design, J. Med. Chem., 59 (2016) 3935-3952.

[20] T. Nittoli, K. Curran, S. Insaf, M. DiGrandi, M. Orlowski, R. Chopra, A. Agarwal, A.Y. Howe, A. Prashad, M.B. Floyd, B. Johnson, A. Sutherland, K. Wheless, B. Feld, J. O'Connell, T.S. Mansour, J. Bloom, Identification of anthranilic acid derivatives as a novel class of allosteric inhibitors of hepatitis C NS5B polymerase, J. Med. Chem., 50 (2007) 2108-2116.

[21] P. Niyomrattanakit, Y.L. Chen, H. Dong, Z. Yin, M. Qing, J.F. Glickman, K. Lin, D. Mueller, H. Voshol, J.Y. Lim, S. Nilar, T.H. Keller, P.Y. Shi, Inhibition of dengue virus polymerase by blocking of the RNA tunnel, J. Virol., 84 (2010) 5678-5686.

[22] P. Che, L. Wang, Q. Li, The development, optimization and validation of an assay for high throughput antiviral drug screening against Dengue virus, In.t J. Clin. Exp. Med., 2 (2009) 363-373. [23] B. Chao, X.-K. Tong, W. Tang, D.-W. Li, P.-L. He, J.-M. Garcia, L.-M. Zeng, A.-H. Gao, L. Yang, J. Li, F.-J. Nan, M. Jacobs, R. Altmeyer, J.-P. Zuo, Y.-H. Hu, Discovery and optimization of 2,4diaminoquinazoline derivatives as a new class of potent dengue virus inhibitors, J. Med. Chem., 55 (2012) 3135-3143.

[24] K.S. Van Horn, X. Zhu, T. Pandharkar, S. Yang, B. Vesely, M. Vanaerschot, J.C. Dujardin, S. Rijal, D.E. Kyle, M.Z. Wang, K.A. Werbovetz, R. Manetsch, Antileishmanial activity of a series of N(2),N(4)disubstituted quinazoline-2,4-diamines, J. Med. Chem., 57 (2014) 5141-5156.

[25] P. Busca, I. McCort, T. Prange, Y. Le Merrer, Synthesis of C-nucleosidic ATP mimics as potential FGFR3 inhibitors, Eur. J. Org. Chem., (2006) 2403-2409.

[26] L. Zhu, J. Jin, C. Liu, C. Zhang, Y. Sun, Y. Guo, D. Fu, X. Chen, B. Xu, Synthesis and biological evaluation of novel quinazoline-derived human Pin1 inhibitors, Bioorg. Med. Chem., 19 (2011) 27972807. 
[27] R. Leenders, J. Heeres, D. Vandenput, J. Guillemont, P. Lewi, Novel Procedure for the Coupling of Sterically Hindered Electron-Deficient Anilines to the 6-Position of the Purine Core, Synth. Commun., 41 (2011) 3246-3250.

[28] P.M. Mader, Trifluoroacetanilide. pKa and Alkaline Hydrolysis Kinetics, J. Am. Chem. Soc., 87 (1965) 3191-3195.

[29] B. Asproni, G. Murineddu, A. Pau, G.A. Pinna, M. Langgard, C.T. Christoffersen, J. Nielsen, J. Kehler, Synthesis and SAR study of new phenylimidazole-pyrazolo[1,5-c]quinazolines as potent phosphodiesterase 10A inhibitors, Bioorg. Med. Chem., 19 (2011) 642-649.

[30] J.L. Kelley, J.A. Linn, M.P. Krochmal, J.W. Selway, 9-Benzyl-6-(dimethylamino)-9H-purines with antirhinovirus activity, J. Med. Chem., 31 (1988) 2001-2004.

[31] F.F.D. Daeyaert, J.M.R. De, J. Heeres, P.A.J. Di Janssen, L.M.H. Koymans, R.G.G. Leenders, P.J. Lewi, D.A.L. Vandenput, H.M. Vinkers Hiv replication inhibiting purine derivatives. WO 2005028479 A3, 2005.

[32] T.M. Chapman, N. Bouloc, R.S. Buxton, J. Chugh, K.E. Lougheed, S.A. Osborne, B. Saxty, S.J. Smerdon, D.L. Taylor, D. Whalley, Substituted aminopyrimidine protein kinase B (PknB) inhibitors show activity against Mycobacterium tuberculosis, Bioorg. Med. Chem. Lett., 22 (2012) 3349-3353. [33] K.S. Van Horn, W.N. Burda, R. Fleeman, L.N. Shaw, R. Manetsch, Antibacterial activity of a series of N2,N4-disubstituted quinazoline-2,4-diamines, J. Med. Chem., 57 (2014) 3075-3093.

[34] L. Ciszewski, L. Waykole, M. Prashad, O. Repic, A practical synthesis of 2-arylamino-6alkylaminopurines from 2,6-dichloropurine, Org. Process. Res. Dev., 10 (2006) 799-802.

[35] S. Houze, N.T. Hoang, O. Lozach, J. Le Bras, L. Meijer, H. Galons, L. Demange, Several Human Cyclin-Dependent Kinase Inhibitors, Structurally Related to Roscovitine, As New Anti-Malarial Agents, Molecules, 19 (2014) 15237-15257.

[36] P. Vincetti, F. Caporuscio, S. Kaptein, A. Gioiello, V. Mancino, Y. Suzuki, N. Yamamoto, E. Crespan, A. Lossani, G. Maga, G. Rastelli, D. Castagnolo, J. Neyts, P. Leyssen, G. Costantino, M. Radi, Discovery of Multitarget Antivirals Acting on Both the Dengue Virus NS5-NS3 Interaction and the Host Src/Fyn Kinases, J. Med. Chem., 58 (2015) 4964-4975.

[37] G. Zou, Y.L. Chen, H. Dong, C.C. Lim, L.J. Yap, Y.H. Yau, S.G. Shochat, J. Lescar, P.Y. Shi, Functional analysis of two cavities in flavivirus NS5 polymerase, J. Biol. Chem., 286 (2011) 14362-14372.

[38] T.L. Yap, T. Xu, Y.L. Chen, H. Malet, M.P. Egloff, B. Canard, S.G. Vasudevan, J. Lescar, Crystal structure of the dengue virus RNA-dependent RNA polymerase catalytic domain at 1.85-angstrom resolution, J. Virol., 81 (2007) 4753-4765.

[39] G.M. Morris, R. Huey, W. Lindstrom, M.F. Sanner, R.K. Belew, D.S. Goodsell, A.J. Olson, AutoDock4 and AutoDockTools4: Automated docking with selective receptor flexibility, J. Comput. Chem., 30 (2009) 2785-2791.

[40] E.F. Pettersen, T.D. Goddard, C.C. Huang, G.S. Couch, D.M. Greenblatt, E.C. Meng, T.E. Ferrin, UCSF Chimera--a visualization system for exploratory research and analysis, J. Comput. Chem., 25 (2004) 1605-1612. 


\section{FIGURE, SCHEME AND TABLE CAPTIONS}

Figure 1: Structures of the most active anti-DENV compounds from our previous work.

Figure 2: compounds with biological activity and sharing some structural aspects with our series or displaying antimicrobial activity.

Figure 3: new envisaged structures for DENV inhibition based on aminopurine or aminoquinazoline scaffolds.

Figure 4: Docking pose for different compounds in cavity B of DENV3 RdRp with residue numbering according to DENV-3 with panel A: reference compound $\mathbf{1 . 9}$ (hydrophobic contacts with Lys329, Trp859, Ile863); panel B: 1.3 from reference [1] (Leu327, Lys329, Trp859 and Ile863); panel C: 15 (Leu327, Lys329, Trp859, Ile863); panel D: 14 (Lys329); panel E: 18a (Trp859 and Ile863); panel F: 18b (Lys329, Trp859 and Ile863).

Scheme 1: a) urea, $160{ }^{\circ} \mathrm{C}, 12 \mathrm{~h}$; b) DIPEA, $\mathrm{POCl}_{3}, 90{ }^{\circ} \mathrm{C}, 6 \mathrm{~h}$; c) acetonitrile, TEA, 2-bromo p-toluidine, $60{ }^{\circ} \mathrm{C}$; d) acetonitrile, TEA, p-toluidine, $90{ }^{\circ} \mathrm{C}$; e) 3-thiophene boronic acid, $\operatorname{Pd}(\mathrm{TPP})_{2} \mathrm{Cl}_{2}$, THF $80^{\circ} \mathrm{C}$.

Scheme 2: i) triflic anhydride, Et $3 \mathrm{~N}, \mathrm{DCM}, \mathrm{rt}, 3 \mathrm{~h}$ (90\%); (ii) $\mathrm{NH}_{2} \mathrm{NH}_{2} / \mathrm{NH}_{2} \mathrm{NH}_{2}$. $2 \mathrm{HCl}$, ethylene glycol, $200{ }^{\circ} \mathrm{C}$, sand bath, $5 \mathrm{~h}(75 \%)$

Scheme 3: i) $\mathrm{PMBCl}, \mathrm{K}_{2} \mathrm{CO}_{3}$, DMF, rt., 24 h (12a: 55\%; 12b: 26\%); ii) $\mathrm{K}_{2} \mathrm{CO}_{3}$, $\mathrm{DME}$, reflux, $24 \mathrm{~h}$ (48\% of 13 (along with $25 \%$ recovery of 12a) and $37 \%$ of 14; iii) TFA, DCM, rt, 5 h (51\%); iv) $\mathrm{K}_{2} \mathrm{CO}_{3}$, DME, reflux, 24 h (35\% of 15).

Scheme 5: envisaged unsuccessful synthesis of 2,6-disubstituted purines

Table 1: Dengue inhibitory activity and cytotoxicity of the target compounds 


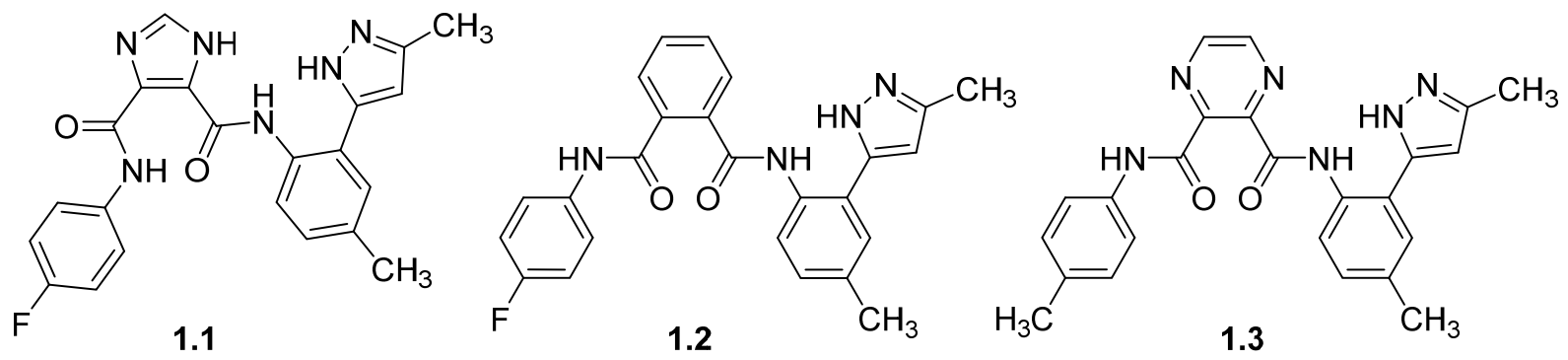

Figure 1

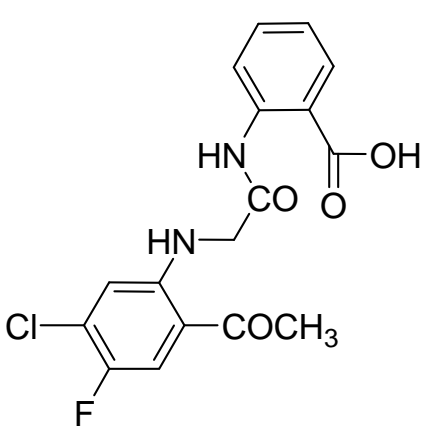

1.4

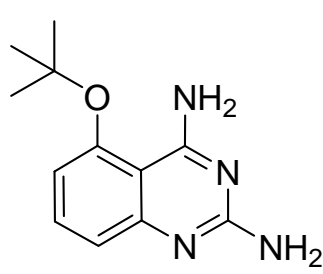

1.7
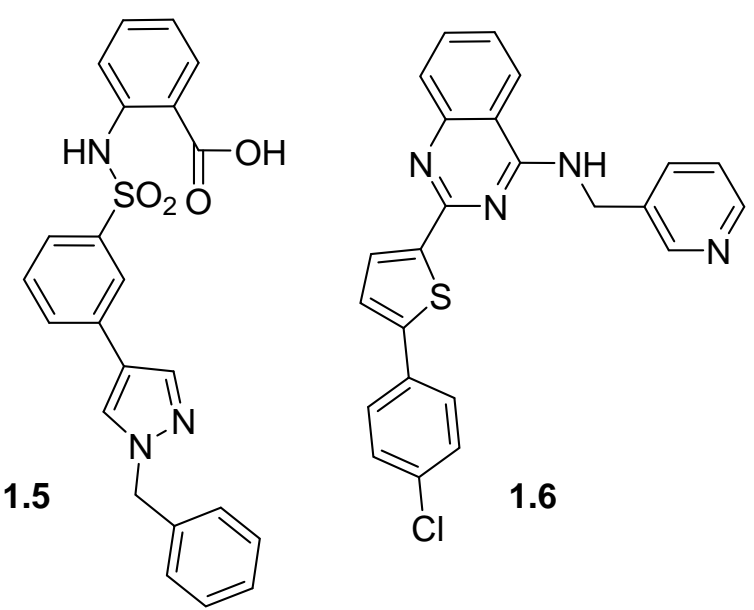

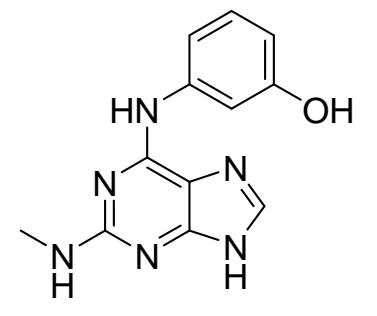

1.9

Figure 2 

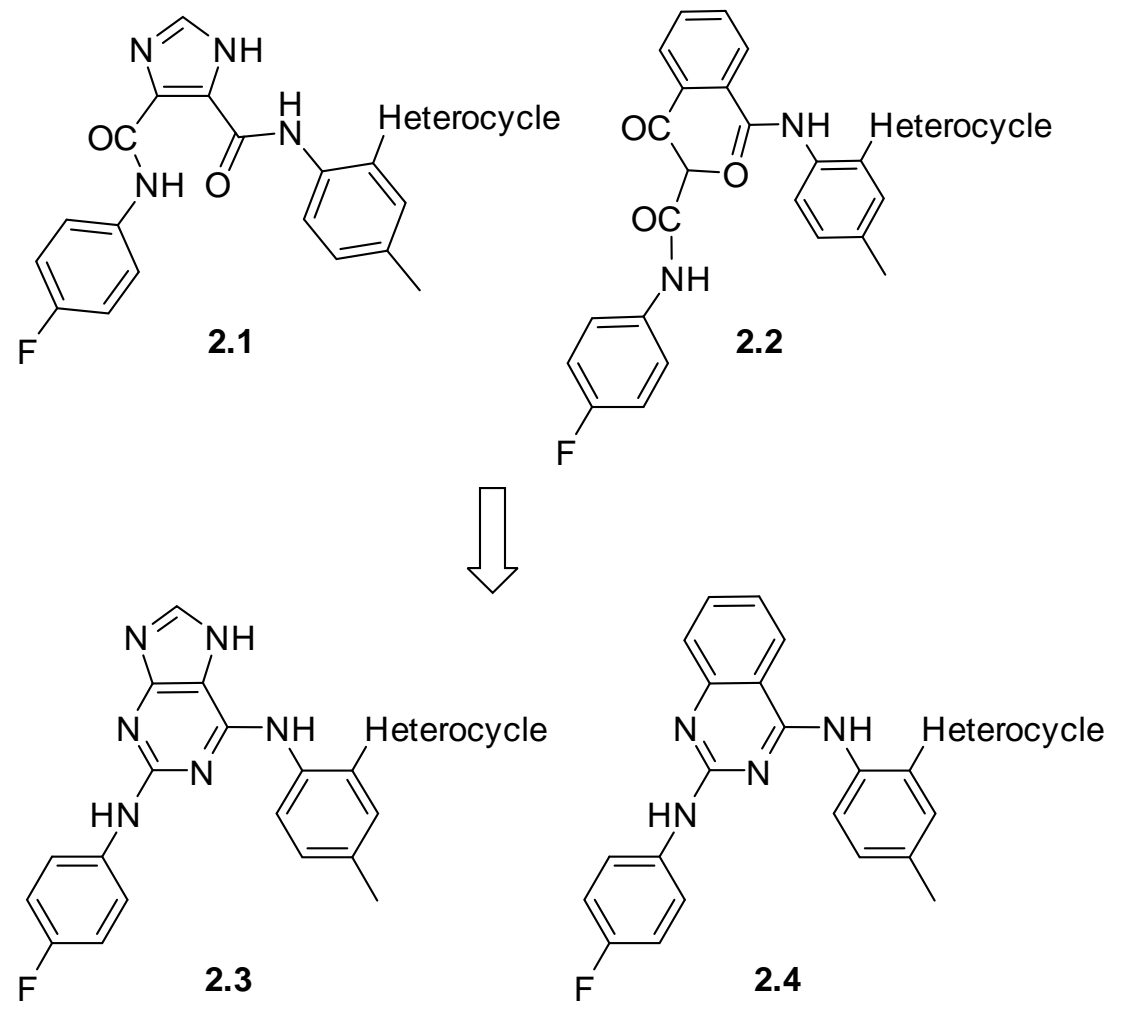

Figure 3
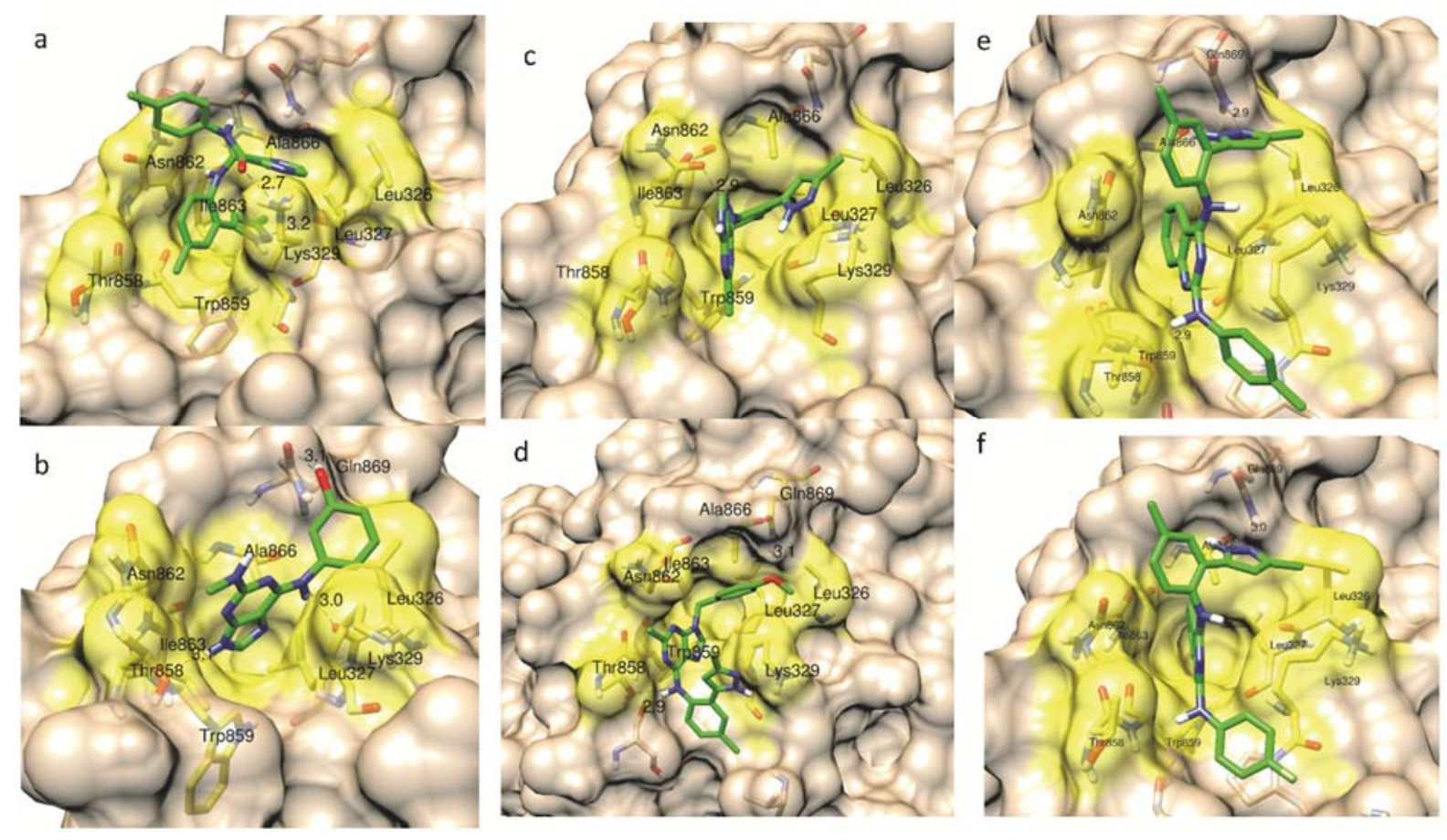

Figure 4 
<smiles>Nc1ccccc1C(=O)O</smiles>

3.1
$\mathrm{H}_{2} \mathrm{~N}_{\mathrm{O}} \mathrm{NH}_{2} \stackrel{\mathrm{a}}{\longrightarrow}$<smiles>Oc1nc(O)c2ccccc2n1</smiles>

3.2<smiles>[10BH]C</smiles><smiles>Clc1nc(Cl)c2ccccc2n1</smiles>

c

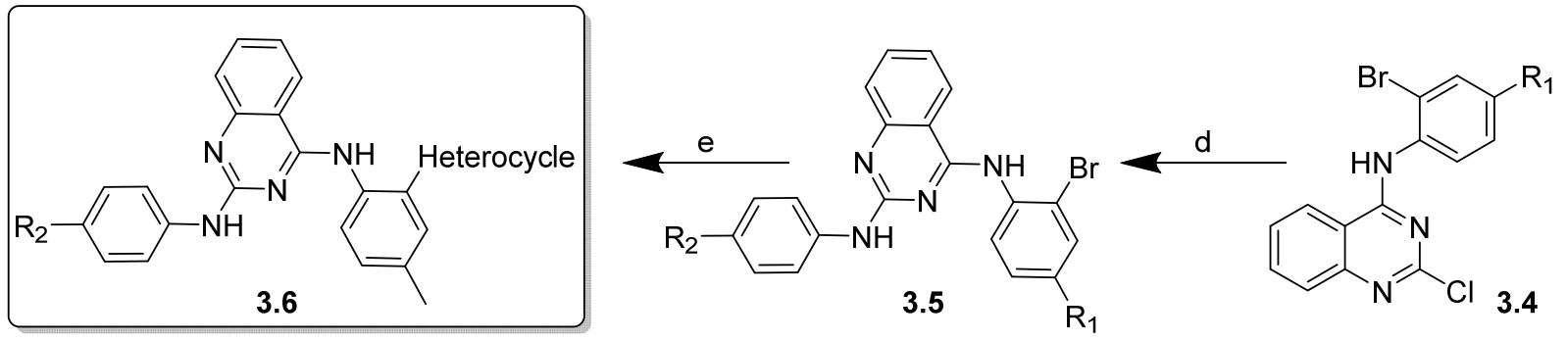

Scheme 1<smiles>Clc1nc(Cl)c2nc[nH]c2n1</smiles>

4<smiles>Clc1nc(Cl)c2ccccc2n1</smiles>

7<smiles>Cc1ccc2nc(C)cc(O)c2c1</smiles>

10

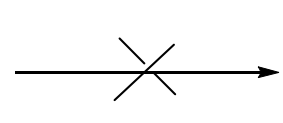<smiles>Cc1ccc(N)c(Br)c1</smiles>

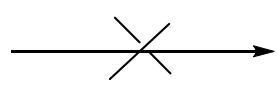

(ii)<smiles>Cc1ccc(Nc2nc(Cl)nc3[nH]cnc23)c(Br)c1</smiles><smiles>Cc1ccc(Nc2nc(Cl)nc3ccccc23)c(Br)c1</smiles>

8<smiles>Cc1ccc(N)c(-c2cc(C)n[nH]2)c1</smiles><smiles>Cc1ccc(N)c(Br)c1</smiles>

5

(i)<smiles>Cc1ccc(NC(=O)C(F)(F)F)c(Br)c1</smiles>

Scheme 2 
<smiles>Clc1nc(Cl)c2nc[nH]c2n1</smiles>

4

11 (iv)<smiles>[R]n1cnc2c(Nc3ccc(C)cc3-c3cc(C)n[nH]3)nc(Cl)nc21</smiles>

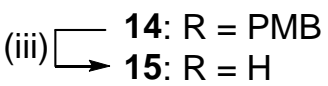<smiles>COc1ccc(Cn2cnc3c(Cl)nc(Cl)nc32)cc1</smiles>

$12 a$<smiles>COc1ccc(Cn2cnc3nc(Cl)nc(Cl)c32)cc1</smiles>

12b

11

(ii)

(ii) 9

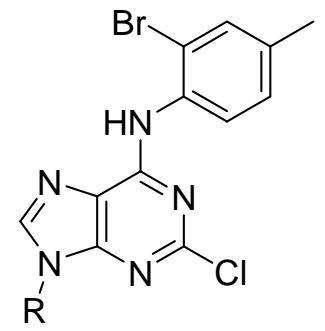

(iii) $\square$ 13: $\mathrm{R}=\mathrm{PMB}$

Scheme 3<smiles>Clc1nc(Cl)c2ccccc2n1</smiles>

(i) 11<smiles>[C-]C</smiles><smiles>Cc1ccc(Nc2nc(Cl)nc3ccccc23)c(Br)c1</smiles>

8<smiles>Cc1ccc(Nc2nc(Cl)nc3ccccc23)c(-c2cc(C)n[nH]2)c1</smiles>

16<smiles>[R]c1ccc(N)cc1</smiles>

(ii)

Scheme 4<smiles>[R]c1ccc(NC2=NN([R]([R])([13CH2])[18OH])c3ccccc3C(Nc3ccc(C)cc3-c3cc(C)n[nH]3)=N2)cc1</smiles>

18b: $R=F$ 


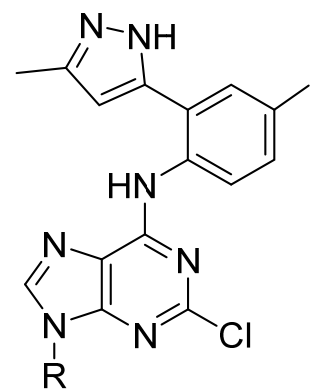

14: $R=P M B$

15: $\mathrm{R}=\mathrm{H}$

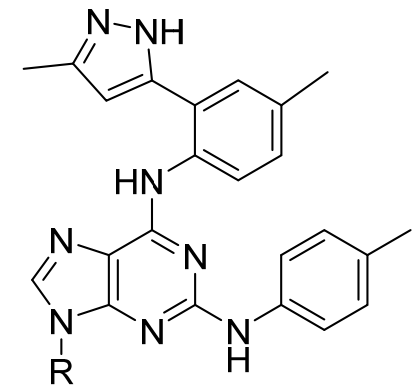

19: $R=P M B$

20: $R=H$

Scheme 5 


\begin{tabular}{ccccc}
\hline compound & MW & $\begin{array}{c}\text { MTS/PMS } \\
\text { CC50 }(\mu \mathrm{m})\end{array}$ & $\begin{array}{c}\text { RT-qPCR } \\
\text { EC50 }(\mu \mathrm{m})\end{array}$ & SI \\
\hline $\mathbf{1 2 a}$ & 308 & 32.4 & 17.6 & 2 \\
$\mathbf{1 2 b}$ & 308 & 12.3 & 9.9 & 1 \\
$\mathbf{1 3}$ & 457 & $>109^{\mathrm{a}}$ & 7.2 & 15 \\
$\mathbf{6}$ & 337 & $>148$ & 33.5 & 4 \\
$\mathbf{1 4}$ & 459 & $>109^{\mathrm{a}}$ & 1.9 & 58 \\
$\mathbf{1 5}$ & 339 & $>147$ & 28.9 & 5 \\
$\mathbf{8}$ & 347 & $>144^{\mathrm{a}}$ & 10.9 & 13 \\
$\mathbf{1 6}$ & 349 & 97 & 9.2 & 11 \\
$\mathbf{1 8 a}$ & 420 & 5.8 & 2.6 & 2 \\
$\mathbf{1 8 b}$ & 424 & 8.7 & 6.7 & 1 \\
$\mathbf{1 . 3}$ & 426 & $>117$ & 0.5 & $>235$ \\
$\mathbf{1 . 9}$ & 256 & 168 & 5.3 & 32 \\
\hline a deviating CC & & $10 \mu \mathrm{m}(\mathbf{1 4}) ; 32 \mu \mathrm{m}(\mathbf{8})$ & \\
& & &
\end{tabular}

